\title{
Polimorfisme Gly972Arg Gen IRS-1 dan Cys981Tyr Gen PTPN1 sebagai Faktor Risiko pada Sindrom Metabolik dengan Riwayat Berat Bayi Lahir Rendah
}

\author{
Hikmat Permana, ${ }^{1}$ Gaga Irawan Nugraha, ${ }^{2}$ Sri Hartini K. S. Kariadi ${ }^{1}$ \\ ${ }^{1}$ Departemen Ilmu Penyakit Dalam, ${ }^{2}$ Departemen Ilmu Gizi Fakultas Kedokteran Universitas \\ Padjadjaran-Rumah Sakir Dr. Hasan Sadikin Bandung
}

\begin{abstract}
Abstrak
Peningkatan prevalensi obesitas terjadi di seluruh dunia dan dapat mengenai semua tingkatan usia. Faktor risiko peningkatan sindrom metabolik berhubungan dengan perubahan gaya hidup, obesitas, dan berat lahir rendah. Penelitian ini dilakukan bertujuan menganalisis genotipe IRS-1, genotipe PTPN1, dan berat bayi lahir rendah (BBLR) sebagai risiko terhadap sindrom metabolik. Pada tahun 2009 terkumpul sebanyak 97 BBLR dan 100 bayi berat lahir normal (BBLN) berusia 20-21 tahun. Penelitian kohort retrospektif ini merupakan bagian penelitian kohort sebelumnya di kecamatan Tanjung Sari pada tahun 1989. Peran genotipe IRS-1, genotipe PTPN1, dan BBLR terhadap sindrom metabolik diuji dengan regresi logistik multipel. Hasil penelitian menunjukkan tidak terdapat hubungan bermakna genotipe IRS-1 dan PTPN1 dengan faktor-faktor sindrom metabolik, tetapi hanya genotipe $I R S-1$ berhubungan signifikan dengan trigliserida $(\mathrm{p}=0,006)$. Polimorfisme Gly972Arg gen $I R S-1$ pada BBLR mempunyai nilai prediksi terhadap peningkatan tekanan darah diastol, lingkaran perut, dan trigliserida. Polimorfisme Cys981Tyr gen PTPN1 menunjukkan faktor risiko terhadap tekanan darah sistol dan kolesterol high density lipoprotein (HDL). Polimorfisme Gly972Arg gen IRS-1 merupakan faktor dominan sebagai penyebab peningkatan tekanan darah diastol, lingkaran perut, dan trigliserida. Simpulan, polimorfisme Cys981Tyr gen PTPN1 merupakan faktor risiko peningkatan tekanan darah sistol dan kolesterol HDL. Bayi berat lahir rendah merupakan faktor risiko peningkatan gula darah puasa. [MKB. 2012;44(3):170-8].
\end{abstract}

Kata kunci: BBLR, Gly972Arg gen IRS-1, Cys981Tyr gen PTPN1, polimorfisme, sindrom metabolik

\section{Role of Polymorphism Gly972Arg Gene IRS-1 and Cys981Tyr Gene PTPN1 as Risk Factors in Metabolic Syndrome with History of Low Birth Weight}

\begin{abstract}
Increasing prevalence of obesity occurs worldwide and can affect all ages levels. Risk factors of increasing metabolic syndrome were associated with changes in lifestyle, obesity and low birth weight (LBW). This study was aimed to analyze the genotype IRS-1, genotype PTPN1 and LBW in metabolic syndrome risk factors. In 2009, this restrospective cohort study was comprised of 97 LBW and 100 normal birth weight (NBW), aged 20-21 years old, from the previous cohort study in District Tanjung Sari since 1989. The role of IRS-1 gene, PTPN1 gene and LBW in the metabolic syndrome factors were analyzed using multiple logistic regressions. The result showed there were no significant relationship between IRS-1 and PTPN1 genotype with metabolic syndrome factors but only IRS-1 genotype was significantly associated with trygliceride $(\mathrm{p}=0.006)$. Gly972Arg IRS-1 gene polymorphism in LBW has predictive value of increasing diastolic blood pressure, waist circumference and trygliceride. Cys 981 Tyr PTPN1 gene polymorphism showed a risk factor for systolic blood pressure and high density lipoprotein (HDL) cholesterol. Gly972Arg IRS-1 gene polymorphism was a dominant factor to increase diastolic blood pressure, waist circumference and trygliceride. In conclusions, Cys981 Tyr PTPN1 gene polymorphism is a risk factor of increased systolic blood pressure and HDL cholesterol, and LBW is the risk factor increasing fasting glucose level. [MKB. 2012;44(3):170-8].
\end{abstract}

Key words: Cys981Tyr gene PTPN1, Gly972Arg gene IRS-1, LBW, metabolic syndrome, polymorphism Korespondensi: Dr. Hikmat Permana, dr., Sp.PD-KEMD, Departemen Ilmu Penyakit Dalam Fakultas edokteran Universitas
Padjadjaran-Rumah Sakit Hasan Sadikin Bandung, jalan Pasirkaliki 190 Bandung, mobile 0811206043/081320517607 e-mailbdo_ek@yahoo.com 


\section{Pendahuluan}

Peningkatan prevalensi obesitas terjadi di seluruh dunia dan dapat mengenai semua tingkatan usia. Keadaan tersebut diduga berhubungan dengan perubahan gaya hidup. ${ }^{1}$ Pada obesitas sering kali terdapat resistensi insulin akibat peningkatan sekresi adipositokin oleh sel lemak. Deteksi dini terhadap resistensi insulin sangat penting untuk mencegah penyakit jantung koroner (PJK) dan disfungsi endotel. Salah satu metode deteksi klinis gangguan metabolisme yaitu dengan menemukan berbagai manifestasi klinis yang dikenal sebagai sindrom metabolik. ${ }^{2}$

Misra dan Khurana ${ }^{3}$ di India menyimpulkan bahwa prevalensi resistensi insulin pada anak pascapubertas dengan indeks massa tubuh (IMT) normal, pada laki-laki sebesar 20\% dan wanita $21,3 \%$. Hasil penelitian ini menimbulkan dugaan bahwa resistensi insulin tidak hanya terjadi pada individu obes tetapi dapat terjadi pada individu dengan berat badan normal bahkan kurang., ${ }^{4,5}$

Beberapa hipotesis menjelaskan resistensi insulin terjadi akibat antara lain bawaan sejak lahir, peran insulin pada bayi, serta hipotesis Barker, thrifty fenotype. ${ }^{5}$ Menurut Barker, ${ }^{5}$ malnutrisi pada masa janin yaitu riwayat berat bayi lahir rendah (BBLR) berkaitan dengan sindrom metabolik, diabetes melitus tipe 2 (DMT2), dan penyakit kardiovaskular di kemudian hari. ${ }^{5}$ Pada BBLR mengalami perubahan struktur, fungsi, metabolisme, dan endokrin yang menetap. ${ }^{5}$ Dengan demikian, pada perkembangan janin telah terjadi perubahan metabolisme yang berkembang menjadi faktor risiko termasuk berkembangnya resistensi insulin. Kejadian resistensi insulin pada BBLR dikuatkan dengan hasil penelitian di kecamatan Tanjung Sari tahun 2003 yang menemukan kejadian dislipidemia dan gangguan toleransi glukosa pada usia 12-13 tahun dengan riwayat BBLR. ${ }^{6}$

Insulin receptor substrate-1 (IRS-1) berperan sangat penting dalam transduksi sinyal insulin, apabila terdapat perubahan pada IRS-1 maka akan terjadi gangguan sinyal transduksi insulin, seperti pada individu tertentu yang mempunyai polimorfisme Gly972Arg gen IRS-1, terjadi perubahan kedudukan asam amino glisin pada posisi kodon 927 diganti oleh asam amino arginin dan menimbulkan gangguan transduksi sinyal insulin. ${ }^{4,7}$

Selain IRS-1 terdapat juga protein tyrosine phosphatase 1B (PTPN1). ${ }^{8}$ Protein tyrosine phosphatase merupakan regulator yang penting pada sistem sinyal negatif transduksi insulin, bertanggung jawab dalam proses defosforilasi reseptor insulin serta substratnya yang mampu untuk menghentikan sinyal transduksi insulin. ${ }^{9}$
Resistensi insulin dapat terjadi akibat gangguan sinyal insulin melalui IRS-1 $1^{9,10}$ atau terjadi sinyal negatif transduksi insulin melalui proses defosforilasi yang melibatkan PTPN1. ${ }^{11-14}$ Protein tyrosine phosphatase $1 \mathrm{~B}$ ini dapat mengalami polimorfisme mengakibatkan tranduksi sinyal insulin akan tetap berlangsung. ${ }^{9,12}$ Kelainan baik pada gen $I R S-1^{10,11}$ dan atau gen $P T P N 1^{12,13}$ menyebabkan kelainan metabolik serta diduga akan lebih mudah dan lebih muda untuk terjadi resistensi insulin, tidak memerlukan peningkatan berat badan sampai obes untuk berkembang menjadi resistensi insulin.

Berdasarkan latar belakang tersebut, maka dilakukan penelitian untuk mengetahui pengaruh polimorfisme gen IRS-1 dan PTPN1 pada variabel subjek sindrom metabolik dengan riwayat BBLR sebagai suatu upaya meningkatkan kewaspadaan deteksi dini sindrom metabolik dan meningkatkan upaya pencegahan penyakit jantung di kemudian hari.

\section{Metode}

Penelitian ini dilakukan pada tahun 2009 di Kecamatan Tanjung Sari merupakan bagian dari penelitian kohort retrospektif pada subjek yang lahir pada tahun 1988-1989 yang mempunyai catatan medis berat badan saat dilahirkan. Tercatat sebanyak 4.449 kelahiran bayi, pada saat penelitian ini dimulai terdapat $3.300(74,17 \%)$ subjek dari jumlah kelahiran tersebut. Pemilihan subjek penelitian melalui randomisasi dan telah terpilih 197 subjek terdiri atas 97 subjek BBLR selanjutnya disebut kelompok BBLR dan 100 subjek bayi berat lahir normal (BBLN) selanjutnya disebut kelompok BBLN, kemudian dilakukan pemeriksaan lingkaran perut, gula darah puasa, profil lipid, dan tekanan darah.

Polimorfisme Gly972Arg gen IRS-1 yaitu suatu polimorfisme gen IRS-1 pada urutan asam amino ke-972 arginin diganti oleh glisin. Produk polymerase chain reaction (PCR) yang didapat sebesar 263 bp, diikuti digesti dengan enzim SmaI. Apabila ada polimorfisme $(\mathrm{GGG} \rightarrow \mathrm{CGG})$ akan didapat fragmen $183 \mathrm{bp}$ dan $80 \mathrm{bp}$, apabila tidak ada polimorfisme akan didapat fragmen sebesar 155 bp, 28 bp, dan 80 bp.

Fragmen ini akan dipisahkan melalui proses elektroforesis gel agarose lalu dideteksi dengan pewarnaan etidium bromid. Genotipe Gly972Arg dianalisis dengan metode PCRRFLP mempergunakan primer 5'CTTCTGT CAGGTGTCCATCC3'(forward) serta primer 5'TGGCGAGGTGTCCACGTAGC3' (reverse).

Polimorfisme Cys981Tyr gen PTPN1 yaitu polimorfisme PTPN1, terjadi penggantian asam 


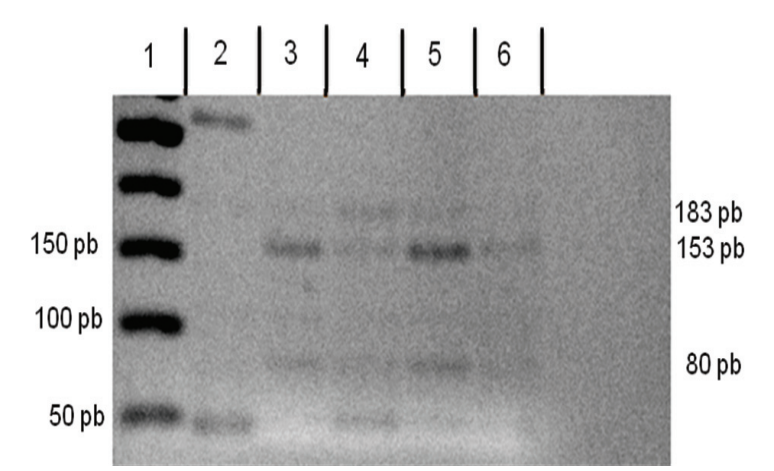

Gambar 1 Hasil Pemotongan Produk PCR Gen IRS-1 dengan Enzim SmaI

amino pada urutan ke-981 dari sistein menjadi tirosin. Primer gen PTPN1 dirancang menurut penelitian pada populasi masyarakat Oji-Cree, Kanada. Genotip Cys981Tyr PTP-1B dianalisis denganmetode PCR-RFLPmenggunakan primerF 5'AACCAGCCGAAGTGAACACTAATAGG 3' Primer, R 5'CCTAGAACAGAAAGTCATTTCC CC 3' dan enzim restriksi AvaI, regio yang dideteksi $981 \mathrm{C} \rightarrow \mathrm{T}$. Disebut polimorfisme apabila: $\mathrm{GGG} \rightarrow \mathrm{CGG}$ didapatkan gambaran fragmen $183 \mathrm{pb}, 153 \mathrm{pb}$, dan $80 \mathrm{pb}$.

Analisis multivariat dilakukan untuk melihat variabel yang berpengaruh pada variabel sindrom metabolik dengan uji regresi logistik multipel bertujuan untuk mencari faktor risiko yang paling dominan terhadap variabel sindrom metabolik.

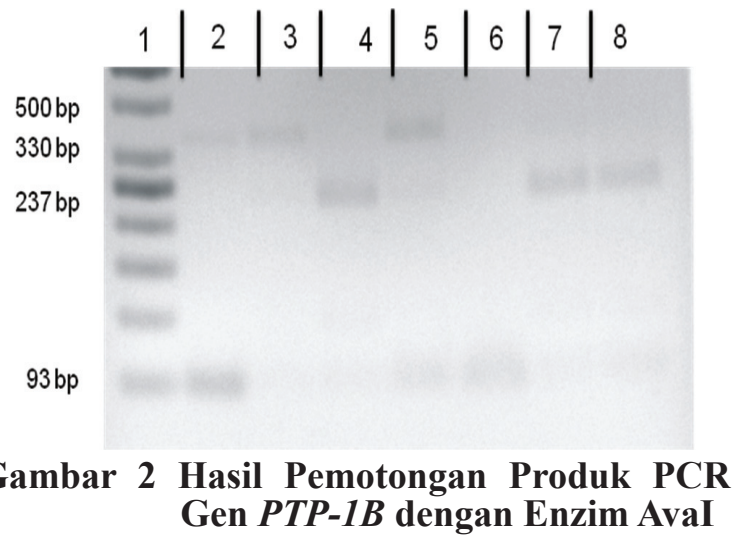

\section{Hasil}

Subjek penelitian berusia 20-22 tahun, terdiri atas 103 laki-laki dan 94 perempuan. Analisis statistik uji-t menggunakan SPSS 16, didapat perbedaan bermakna tekanan darah sistol pada kedua kelompok (Tabel 1).

Kelompok BBLR bila dibandingkan dengan kelompok BBLN mempunyai tekanan darah sistol rata-rata yang berbeda bermakna $(p<0,05)$. Perbandingan lingkaran perut, indeks massa tubuh (IMT), tekanan darah diastol, gula darah puasa, kadar kolesterol total, kolesterol HDL, kolesterol LDL, dan trigliserida rata-rata pada kelompok BBLR dan BBLN tidak berbeda bermakna $(\mathrm{p}>0,05)($ Tabel 2$)$

Variabel sindrom metabolik berupa lingkar

Tabel 1 Karakteristik Umum Kelompok BBLR dan BBLN

\begin{tabular}{|c|c|c|c|c|c|c|c|}
\hline Variabel & Kelompok & Min & Maks & Rata-rata & SD & $\mathbf{t}$ & $\mathbf{p}$ \\
\hline \multirow{2}{*}{ Lingkaran perut $(\mathrm{cm})$} & BBLR & 56,20 & 91,25 & 68,81 & 7,57 & 2,51 & 0,114 \\
\hline & BBLN & 56,00 & 99,55 & 70,49 & 7,31 & & \\
\hline \multirow{2}{*}{ IMT $\left(\mathrm{kg} / \mathrm{m}^{2}\right)$} & BBLR & 15,28 & 29,42 & 20,31 & 3,24 & 1,21 & 0,272 \\
\hline & BBLN & 16,36 & 32,47 & 20,80 & 3,01 & & \\
\hline \multirow{2}{*}{$\begin{array}{l}\text { Tekanan darah sistol } \\
(\mathrm{mmHg})\end{array}$} & BBLR & 100 & 160 & 116,79 & 10,68 & 0,005 & $<0,001$ \\
\hline & BBLN & 90 & 150 & 117,24 & 10,90 & & \\
\hline \multirow{2}{*}{$\begin{array}{l}\text { Tekanan darah diastol } \\
(\mathrm{mmHg})\end{array}$} & BBLR & 100 & 70 & 77,97 & 7,03 & 0,06 & 0,812 \\
\hline & BBLN & 100 & 60 & 77,73 & 7,12 & & \\
\hline \multirow{2}{*}{ Gula darah puasa $(\mathrm{mg} / \mathrm{dL})$} & BBLR & 118 & 70 & 86,19 & 7,63 & 0,05 & 0,821 \\
\hline & BBLN & 146 & 66 & 85,90 & 7,63 & & \\
\hline \multirow{2}{*}{ Kolesterol total (mg/dL) } & BBLR & 790 & 71 & 163,81 & 67,08 & 0,007 & 0,797 \\
\hline & BBLN & 240 & 47 & 161,90 & 31,23 & & \\
\hline \multirow{2}{*}{ Kolesterol HDL (mg/dL) } & BBLR & 70 & 29 & 44,78 & 9,24 & 1,12 & 0,292 \\
\hline & BBLN & 63 & 23 & 43,48 & 8 & & \\
\hline \multirow{2}{*}{ Kolesterol LDL (mg/dL) } & BBLR & 460 & 34 & 102,59 & 42,02 & 0,09 & 0,765 \\
\hline & BBLN & 167 & 46 & 104,04 & 24,09 & & \\
\hline \multirow{2}{*}{ Trigliserida (mg/dL) } & BBLR & 482 & 32 & 85,87 & 54,12 & 0,58 & 0,448 \\
\hline & BBLN & 223 & 26 & 91,36 & 47,11 & & \\
\hline
\end{tabular}

Keterangan: uji-t 
Tabel 2 Gambaran Prevalensi Variabel Sindrom Metabolik pada BBLR dan BBLN

\begin{tabular}{|c|c|c|c|c|c|c|c|}
\hline \multirow[t]{2}{*}{ Variabel } & \multicolumn{2}{|c|}{$\begin{array}{c}\text { BBLR } \\
\text { (97) }\end{array}$} & \multicolumn{2}{|c|}{$\begin{array}{c}\text { BBLN } \\
(\mathbf{1 0 0 )}\end{array}$} & \multirow[t]{2}{*}{ p } & \multirow[t]{2}{*}{$\mathbf{R R}$} & \multirow[t]{2}{*}{ 95\% IK } \\
\hline & n & $\%$ & $\mathrm{n}$ & $\%$ & & & \\
\hline $\begin{array}{l}\text { Lingkar perut } \\
\qquad>90 \mathrm{~cm} \text { (perempuan) } \\
\quad>80 \mathrm{~cm} \text { (laki-laki) }\end{array}$ & 7 & 7,2 & 7 & 7,0 & 0,621 & 0,50 & $0,92-2,76$ \\
\hline $\begin{array}{l}\text { Sistol } \\
\qquad \geq 140 \mathrm{mmHg}\end{array}$ & 5 & 5,2 & 6 & 6,0 & 0,796 & 0,92 & $0,47-1,78$ \\
\hline $\begin{array}{l}\text { Diastol } \\
\qquad \geq 90 \mathrm{mmHg}\end{array}$ & 13 & 13,4 & 12 & 12,0 & 0,768 & 1,06 & $0,71-1,60$ \\
\hline $\begin{array}{l}\text { Gula darah puasa } \\
\quad>100 \mathrm{mg} / \mathrm{dL}\end{array}$ & 5 & 5,2 & 8 & 8,0 & 0,421 & 0,77 & $0,38-1,55$ \\
\hline $\begin{array}{l}\text { HDL } \\
\text { Laki-laki }<40 \mathrm{mg} / \mathrm{dL} \\
\text { Perempuan }<50 \mathrm{mg} / \mathrm{dL}\end{array}$ & 47 & 29,9 & 47 & 34,0 & 0,946 & 1,01 & $0,76-1,34$ \\
\hline $\begin{array}{l}\text { Trigliserida } \\
\qquad \geq 150 \mathrm{mg} / \mathrm{dL}\end{array}$ & 6 & 6,2 & 8 & 8,0 & 0,620 & 0,86 & $0,46-1,61$ \\
\hline
\end{tabular}

Keterangan: uji chi-kuadrat

perut, tekanan darah sistol, tekanan darah diastol, kadar gula darah puasa, kadar kolesterol high density lipoprotein (HDL), dan kadar trigliserida. Analisis menggunakan uji chi-kuadrat dengan derajat kepercayaan $95 \%$.

Gambaran prevalensi proporsi kadar gula darah $>100 \mathrm{mg} / \mathrm{dL}$ kelompok BBLR tidak berbeda bermakna bila dibandingkan dengan BBLN ( $p=0,421)$. Peningkatan gula darah puasa sebesar 0,77 kali pada kelompok BBLR bila dibandingkan dengan BBLN. Kadar kolesterol
HDL abnormal pada kelompok BBLR lebih rendah dibandingkan dengan BBLN, tetapi tidak berbeda bermakna secara statistik $(p=0,946)$. Peluang kadar kolesterol HDL yang abnormal sebesar 1,01 kali pada kelompok BBLR. Kadar trigliserida $>150 \mathrm{mg} / \mathrm{dL}$ pada kelompok BBLR didapatkan proporsi sebesar $6 \%$ lebih rendah tidak bermakna bila dibandingkan dengan BBLN $8 \%(p=0,620)$. Peluang terjadi kadar trigliserida abnormal sebesar 0,86 kali pada kelompok BBLR (Tabel 2).

Tabel 3 Hubungan Genotipe IRS-1 dengan Variabel Sindrom Metabolik

\begin{tabular}{|c|c|c|c|}
\hline \multirow[t]{2}{*}{ Variabel } & $\begin{array}{c}\text { Polimorfisme } \\
\text { Gly972 Arg Gen IRS-1 } \\
\end{array}$ & Alamiah Gen $I R S-1$ & \multirow[t]{2}{*}{$\mathbf{p}$} \\
\hline & n & $\mathbf{n}$ & \\
\hline Lingkar perut $(\mathrm{n}=14)$ & 5 & 9 & 0,336 \\
\hline \multicolumn{4}{|l|}{$\begin{array}{l}>90 \mathrm{~cm} \text { (perempuan) } \\
>80 \mathrm{~cm} \text { (laki-laki) }\end{array}$} \\
\hline $\begin{array}{l}\text { Sistol }(\mathrm{n}=11) \\
\quad>140 \mathrm{mmHg}\end{array}$ & 1 & 10 & 1,000 \\
\hline $\begin{array}{r}\text { Diastol }(\mathrm{n}=25) \\
\quad>90 \mathrm{mmHg}\end{array}$ & 3 & 22 & 0,715 \\
\hline $\begin{array}{l}\text { Gula darah puasa }(\mathrm{n}=13) \\
\quad>100 \mathrm{mg} / \mathrm{dL}\end{array}$ & 2 & 11 & 0,363 \\
\hline $\begin{array}{l}\text { HDL }(\mathrm{n}=94) \\
\text { Laki-laki }<40 \mathrm{mg} / \mathrm{dL} \\
\text { Wanita }<50 \mathrm{mg} / \mathrm{dL}\end{array}$ & 11 & 83 & 0,756 \\
\hline $\begin{array}{l}\text { Trigliserida }(\mathrm{n}=13) \\
>150 \mathrm{mg} / \mathrm{dL}\end{array}$ & 5 & 8 & 0,006 \\
\hline
\end{tabular}

Keterangan: uji chi-kuadrat 
Tabel 4 Hubungan Genotipe PTPN1 dengan Variabel Sindrom Metabolik

\begin{tabular}{|c|c|c|c|c|}
\hline \multirow{3}{*}{ Variabel } & \multicolumn{3}{|c|}{ Genotipe PTPN1 } & \multirow{3}{*}{$\mathbf{p}$} \\
\hline & $\mathrm{CC}$ & CT & TT & \\
\hline & n & $\mathbf{n}$ & $\mathbf{n}$ & \\
\hline $\begin{array}{l}\text { Lingkar perut } \\
\quad>90 \mathrm{~cm} \text { (perempuan) } \\
>80 \mathrm{~cm} \text { (laki-laki) }\end{array}$ & 0 & 3 & 1 & 0,374 \\
\hline $\begin{array}{l}\text { Sistol } \\
\qquad>140 \mathrm{mmHg}\end{array}$ & 0 & 9 & 2 & 0,039 \\
\hline $\begin{array}{l}\text { Diastol } \\
\quad>90 \mathrm{mmHg}\end{array}$ & 5 & 13 & 7 & 0,981 \\
\hline $\begin{array}{l}\text { Gula darah puasa } \\
>100 \mathrm{mg} / \mathrm{dL}\end{array}$ & 1 & 8 & 4 & 0,433 \\
\hline $\begin{array}{l}\text { HDL } \\
\text { Laki-laki }<40 \mathrm{mg} / \mathrm{dL} \\
\text { Wanita }<50 \mathrm{md} / \mathrm{dL}\end{array}$ & 19 & 54 & 24 & 0,799 \\
\hline $\begin{array}{l}\text { Trigliserida } \\
\quad>150 \mathrm{mg} / \mathrm{dL}\end{array}$ & 1 & 10 & 3 & 0,262 \\
\hline
\end{tabular}

Keterangan: uji chi-kuadrat

Kelompok gen IRS-1 alamiah dengan lingkar perut abnormal lebih banyak dibandingkan dengan kelompok polimorfisme Gly972Arg gen IRS-1, namun hasil uji chi-kuadrat menunjukkan tidak terdapat hubungan bermakna genotipe IRS-1 dengan lingkar perut abnormal $(\mathrm{p}=0,336)$ (Tabel 3). Kelompok subjek yang mempunyai gen IRS alamiah dengan tekanan darah sistol abnormal lebih banyak dibandingkan dengan kelompok polimorfisme Gly972Arg gen IRS-1, namun hasil uji statistik tidak terdapat hubungan genotipe IRS-1 dengan tekanan darah sistol $(\mathrm{p}=1,000)$. Subjek penelitian dengan gen IRS alamiah dengan tekanan darah diastol abnormal lebih banyak dibandingkan dengan kelompok polimorfisme Gly972Arg gen IRS-1, namun hasil uji statistik menunjukkan tidak terdapat hubungan bermakna genotipe IRS-1 dengan tekanan darah diastol $(\mathrm{p}=0,715)$.

Kelompok gen IRS-1 alamiah dengan gangguan gula darah puasa lebih banyak bila dibandingkan dengan kelompok polimorfisme Gly972Arg gen IRS-1, namun hasil uji statistik menunjukkan tidak terdapat hubungan bermakna genotipe $I R S-1$ dengan gula darah puasa terganggu $(\mathrm{p}=0,363)$. Kelompok gen IRS- 1 alamiah dengan kadar kolesterol HDL abnormal lebih banyak dibandingkan dengan kelompok polimorfisme Gly972Arg gen IRS-1, namun hasil uji statistik tidak terdapat hubungan bermakna genotipe IRS-1 dengan kadar kolesterol HDL abnormal $(\mathrm{p}=0,756)$.

Kelompok gen IRS-1 alamiah dengan kadar trigliserida abnormal lebih banyak dibandingkan dengan polimorfisme Gly972Arg gen IRS-1 dan hasil uji statistik menunjukkan hubungan yang bermakna genotipe IRS-1 dengan kadar trigliserida $>150 \mathrm{mg} / \mathrm{dL} \quad(\mathrm{p}=0,006)$. Lingkaran perut abnormal terbanyak pada genotip PTPN1 berupa perubahan kedudukan basa nukleotida C (sitosin) pada basa ketiga pada urutan ke-981 menjadi T (thymin) atau CT $(\mathrm{p}=0,374)$ (Tabel 4).

Tekanan darah sistol abnormal terbanyak pada genotipe CT gen PTPN1 yaitu sebesar $81,85 \%$ dan hasil uji statistik menunjukkan hubungan bermakna tekanan darah sistol abnormal dengan genotipe CT gen PTPN1 CT $(\mathrm{p}=0,039)$. Tekanan darah diastol abnormal terbanyak pada genotipe CT gen PTPN1 sebesar 52,0\%, namun hasil uji statistik tidak terdapat hubungan bermakna genotip PTPN1 dengan tekanan darah diastol $(\mathrm{p}=0,981)$. Gangguan gula darah puasa, kadar kolesterol total abnormal, kadar kolesterol HDL abnormal, kadar trigliserida abnormal terbanyak pada genotip CT gen PTPN1 (Tabel 4).

Setelah dilakukan pemodelan dengan uji regresi logistik multipel, didapatkan model terakhir faktor-faktor yang berhubungan dengan lingkar perut dengan nilai prediksi yang dominan yaitu polimorfisme Gly972Arg gen IRS-1 dengan nilai prediksi sebesar $-1,176(\mathrm{p}=0,319$ dengan nilai $\mathrm{RR}=0,31)$ (Tabel 5). Hal tersebut menunjukkan polimorfisme Gly972Arg gen IRS-1 merupakan prediktor yang paling dominan berhubungan dengan lingkar perut. Nilai prediksi yang paling dominan terhadap tekanan darah sistol yaitu polimorfisme gen $P T P N 1$ dengan nilai prediksi sebesar 1,$440 ; \mathrm{p}=0,070 ; \mathrm{RR}=4,22$ menunjukkan bahwa polimorfisme gen PTPN1 merupakan prediktor yang paling dominan berhubungan 
Tabel 5 Faktor yang Berhubungan dengan Variabel Sindrom Metabolik melalui Analisis Regresi Multiple Logistic

\begin{tabular}{|c|c|c|c|c|c|}
\hline Model & Variabel & Koefisien $\beta$ & SE & $\mathbf{p}$ & RR (95\% IK) \\
\hline \multicolumn{6}{|c|}{ Lingkaran perut } \\
\hline \multirow[t]{3}{*}{ Awal } & Polimorfisme gen $I R S-1$ & $-1,320$ & 1,198 & 0,271 & $-(0,03-2,79)$ \\
\hline & $\begin{array}{l}\text { Polimorfisme gen } \\
\text { PTPN1 }\end{array}$ & 0,857 & 1,184 & 0,469 & $-(0,23-23,99)$ \\
\hline & $\mathrm{BBL}$ & 1,014 & 1,186 & 0,393 & $-(0,27-28,17)$ \\
\hline \multirow{2}{*}{ Akhir } & polimorfisme gen $I R S-1$ & $-1,176$ & 1,181 & 0,319 & $0,31 \quad(0,03-3,12)$ \\
\hline & Konstanta & 4,066 & & & \\
\hline \multicolumn{6}{|l|}{ TD sistol } \\
\hline \multirow[t]{3}{*}{ Awal } & Polimorfisme gen IRS-1 & $-0,010$ & 1,090 & 0,993 & $-(0,12-8,38)$ \\
\hline & $\begin{array}{l}\text { Polimorfisme gen } \\
\text { PTPN1 }\end{array}$ & 1,450 & 0,804 & 0,071 & $-(0,88-20,60)$ \\
\hline & $\mathrm{BBL}$ & $-0,057$ & 0,636 & 0,929 & $-(0,27-3,28)$ \\
\hline \multirow[t]{2}{*}{ Akhir } & $\begin{array}{l}\text { Polimorfisme gen } \\
\text { PTPN1 }\end{array}$ & 1,440 & 0,795 & 0,070 & $4,22(0,88-20,05)$ \\
\hline & Konstanta & 2,367 & & & \\
\hline \multicolumn{6}{|c|}{ TD diastol } \\
\hline \multirow[t]{3}{*}{ Awal } & Polimorfisme gen IRS-1 & $-0,272$ & 0,671 & 0,685 & $0,76(0,21-2,83)$ \\
\hline & $\begin{array}{l}\text { Polimorfisme gen } \\
\text { PTPN1 }\end{array}$ & $-0,033$ & 0,436 & 0,939 & $0,96(0,41-2,27)$ \\
\hline & BBLR & $-0,111$ & 0,436 & 0,799 & $0,89(0,38-2,10)$ \\
\hline \multirow[t]{2}{*}{ Akhir } & Polimorfisme gen IRS-1 & 1,959 & 0,228 & $<0,001$ & $0,75(0,20-2,79)$ \\
\hline & Konstanta & 1,929 & & & \\
\hline \multicolumn{6}{|c|}{ Gula darah puasa } \\
\hline \multirow[t]{3}{*}{ Awal } & Polimorfisme gen IRS-1 & $-0,643$ & 0,816 & 0,430 & $0,53(0,11-2,59)$ \\
\hline & $\begin{array}{l}\text { Polimorfisme gen } \\
\text { PTPN1 }\end{array}$ & 0,301 & 0,600 & 0,616 & $1,35(0,41-4,38)$ \\
\hline & BBLR & 0,444 & 0,601 & 0,459 & $1,56(0,48-5,06)$ \\
\hline \multirow[t]{2}{*}{ Akhir } & BBLR & 0,470 & 0,589 & 0,425 & $1,60(0,51-5,07)$ \\
\hline & Konstanta & 2,442 & & & \\
\hline \multicolumn{6}{|c|}{ Kadar HDL } \\
\hline \multirow[t]{3}{*}{ Awal } & Polimorfisme gen IRS-1 & $-0,159$ & 0,485 & 0,743 & $0,85(0,33-2,21)$ \\
\hline & $\begin{array}{l}\text { Polimorfisme gen } \\
\text { PTPN1 }\end{array}$ & 0,200 & 0,291 & 0,491 & $1,22(0,69-2,16)$ \\
\hline & BBLR & $-0,050$ & 0,290 & 0,864 & $0,95(0,54-1,68)$ \\
\hline \multirow[t]{2}{*}{ Akhir } & $\begin{array}{l}\text { Polimorfisme gen } \\
\text { PTPN1 }\end{array}$ & 0,188 & 0,286 & 0,511 & $1,21(0,69-2,11)$ \\
\hline & Konstanta & $-0,057$ & & & \\
\hline \multicolumn{6}{|c|}{ Kadar trigliserida } \\
\hline \multirow[t]{3}{*}{ Awal } & Polimorfisme gen IRS-1 & $-2,034$ & 0,645 & 0,002 & $0,13(0,04-0,46)$ \\
\hline & $\begin{array}{l}\text { Polimorfisme gen } \\
\text { PTPN1 }\end{array}$ & 0,937 & 0,645 & 0,147 & $2,55(0,71-9,03)$ \\
\hline & BBLR & 0,246 & 0,596 & 0,679 & $1,27(0,39-4,11)$ \\
\hline \multirow[t]{2}{*}{ Akhir } & Polimorfisme gen IRS-1 & $-1,903$ & 0,623 & 0,002 & $0,15(0,04-0,51)$ \\
\hline & Konstanta & 2,933 & & & \\
\hline
\end{tabular}

Keterangan: uji regresi logistik multipel 
dengan tekanan darah sistol.

Nilai prediksi yang dominan terhadap tekanan darah diastol yaitu polimorfisme gen IRS dengan nilai prediksi sebesar 1,$959 ; \mathrm{p}<0,001 ; \mathrm{RR}=0,75$ : artinya subjek penelitian disertai polimorfisme gen IRS memiliki peluang 0,75 kali lebih besar dibandingkan dengan subjek penelitian dengan gen IRS alamiah.

Nilai prediksi dominan terhadap gula darah puasa yaitu BBLR sebesar 0,$470 ; \mathrm{p}=0,425$; $\mathrm{RR}=1,60$ : artinya subjek BBLR memiliki peluang 1,60 kali lebih besar dibandingkan dengan subjek BBLN.

Nilai prediksi yang dominan terhadap kolesterol HDL yaitu polimorfisme gen PTPN1 dengan nilai prediksi sebesar 0,$188 ; \mathrm{p}=0,511$; $\mathrm{RR}=1,21$ : artinya subjek penelitian dengan polimorfisme gen PTPN1 memiliki peluang 1,21 kali lebih besar dibandingkan dengan subjek penelitian gen PTPNI alamiah.

Nilai prediksi yang paling dominan terhadap trigliserida yaitu polimorfisme gen IRS dengan nilai prediksi sebesar $-1,903 ; p=0,002 ; R R=0,15$ : artinya subjek penelitian dengan polimorfisme gen IRS memiliki peluang 0,15 kali lebih besar dibandingkan dengan subjek penelitian gen IRS alamiah.

\section{Pembahasan}

Hasil penelitian memberikan temuan penting mengenai peran varian Gly972Arg gen IRS-1 pada gangguan metabolisme terkait resistensi insulin. Terjadinya varian Gly972Arg gen IRS1 disebabkan BBLR atau sebaliknya varian tersebut mendahului BBLR. Mutasi pada varian Gly972Arg gen IRS-1 memengaruhi struktur tersier IRS-1 yang menyebabkan cacat pengikat pada PI3K dan mengganggu metabolisme glukosa. ${ }^{10,15}$ Mekanisme terjadi varian Gly972Arg gen IRS-1 sampai saat ini masih diperdebatkan. Penyebab resistensi insulin pada BBLR juga sampai saat ini masih belum sepenuhnya dimengerti dan terdapat dugaan disebabkan oleh cacat pascareseptor. Penyebab cacat pascareseptor tersebut belum sepenuhnya diketahui dan tampaknya bersifat multifaktor. ${ }^{16}$ Cacat pascareseptor yang menyebabkan resistensi insulin yaitu gangguan pada kaskade sistem signaling insulin antara lain polimorfisme Gly972Arg gen $I R S-1^{7}$ dan polimorfisme Cys981Tyr gen PTPN1. 11-14 Walaupun kedua varian genotipe tersebut masih diperdebatkan tetapi secara umum dipercayai bahwa kedua varian tersebut berperan pada resistensi insulin.

Dalam periode dekade terakhir banyak peneliti yang mengamati hubungan polimorfisme
Arg972Gly gen IRS-1 dengan diabetes melitus tipe 2 dengan kesimpulan hasil yang tidak konsisten, namun metaanalisis dari 27 penelitian, pada 3.408 diabetes melitus dan 5.419 subjek normal, disimpulkan terdapat peningkatan peluang risiko diabetes melitus sebesar 1,25 kali $(95 \% \mathrm{IK}=1,05-1,48) .{ }^{9}$ Pada BBLR berhubungan dengan polimorfisme Arg972Gly gen IRS-1. Frekuensi polimorfisme Arg972Gly gen IRS1 meningkat pada bayi baru lahir dengan berat badan $<3.000$ gram $(p=0,041) .{ }^{15}$

Varian Arg972Gly merupakan varian yang paling sering ditemukan di antara 2 sisi potensial proses fosforilasi tirosin yang terlibat dengan pengikatan p85 sub unit PI3Kinase. Varian ini mengganggu signaling insulin. ${ }^{16}$ Pada kelompok berbeda, ditemukan prevalensi sedikit lebih tinggi pada diabetes melitus tipe 2 dibandingkan dengan nondiabetes. ${ }^{10}$ Polimorfisme Arg972Gly gen IRS1 tidak terkait dengan resistensi insulin pada DMT2 dewasa, tetapi mungkin terkait dengan kadar insulin dan glukosa darah yang tinggi. ${ }^{16,17}$ Pada remaja gemuk dengan varian Arg972Gly meningkatkan resistensi insulin terutama dalam bentuk heterozigot. ${ }^{18,19}$

Fungsi IRS-1 salah satunya sebagai kunci dowmstream signaling molekul pada reseptor insulin dan reseptor insulin like growth factor-1. Perubahan genetik pada IRS-1 sangat potensial memengaruhi perkembangan resistensi insulin. ${ }^{15}$ Pemeriksaan IRS-1 telah diketahui beberapa varian genetik yang paling sering perubahan pada kodon 972 dari Arg menjadi Gly. Polimorfisme ini ditemukan pada $5 \%$ populasi normal dan $10 \%$ pada diabetes melitus tipe 2 serta pembawa varian G972R meningkatkan risiko diabetes melitus tipe 2 sebesar $25 \%$. $^{11}$

Bento dkk. ${ }^{11}$ menyimpulkan bahwa terdapat hubungan antara polimorfisme gen IRS-1 akibat perubahan Gly972Arg dan diabetes melitus tipe 2. Hasil penelitian ini belum dapat menjelaskan semua penelitian sebelumnya, namun akhir-akhir ini secara metaanalisis dari 27 penelitian pada 3.408 penderita DMT2 dan 50.419 kontrol normal dinyatakan bahwa pembawa Arg972Gly terdapat pada penderita DMT2 dan terjadi peningkatan risiko diabetes melitus sebesar 1,25 kali (IK 95\% $1,05-1,48){ }^{9}{ }^{9}$

Varian Gly972Arg dari IRS-1 lebih sering ditemukan pada BBLR dan individu lebih gemuk. Pada penelitian ini, variabel lingkaran perut tidak terdapat korelasi bermakna walaupun lingkaran perut abnormal lebih banyak ditemukan pada kelompok gen IRS-1 alamiah. Hasil ini berbeda dengan hasil penelitian yang dilakukan oleh Villuendas dkk. ${ }^{16}$ bahwa tidak terdapat hasil IMT yang lebih tinggi secara bermakna pada polimorfisme Gly972Ärg gen IRS-1 dan juga 
tidak ditemukan perbedaan bermakna pada parameter nisbah lingkar pinggang panggul. Secara teoritis, kemungkinan disebabkan jaringan adiposa abdomen lebih aktif melakukan lipolisis, sehingga subjek dengan IMT yang lebih tinggi lebih mudah terjadi resistensi insulin. Hal ini dapat meningkatkan asam lemak bebas sehingga akan menghambat bersihan (clearance) insulin, selain itu polimorfisme Gly972Arg gen IRS-1 juga menyebabkan terjadinya hiperinsulinemia. Hiperinsulinemia mengakibatkan peningkatan berat badan. Peningkatan berat badan yang tidak proporsional dengan tinggi badan menyebabkan IMT meningkat. ${ }^{15,19}$ Artinya, polimorfisme gen IRS-1 juga memengaruhi berat badan, terutama bila dianalisis pada penderita resistensi insulin.

Hubungan bermakna antara polimorfisme Gly972Arg gen IRS-1 dan peningkatan kadar trigliserida $>150 \mathrm{mg} / \mathrm{dL} \quad(\mathrm{p}=0,006)$, walaupun tidak ditemukan perbedaan kadar trigliserida antara kelompok berat badan lahir rendah dan normal. Hal ini dapat dijelaskan bahwa pada individu dengan polimorfisme Gly972Arg gen IRS- 1 akan meningkatkan resistensi insulin. ${ }^{7,10}$

Otot rangka merupakan tempat kerja utama insulin dan berhubungkan dengan berkembangnya resistensi insulin di seluruh tubuh. Mekanisme terjadinya gangguan penyerapan glukosa ke dalam otot belum sepenuhnya dimengerti karena bersifat poligenik, namun terdapat dugaan bahwa kadar asam lemak bebas (free fatty acid/FFA) yang tinggi menghambat penyerapan tersebut. Pada individu normal dan gemuk ditemukan bahwa sensitivitas insulin seluruh tubuh berbanding terbalik dengan kadar asam lemak bebas, ${ }^{19}$ dengan demikian dapat disimpulkan bahwa terdapat hubungan kausal independen dengan adipositas seluruh tubuh.

Hampir semua variabel sindrom metabolik ternyata tidak ada hubungan dengan genotipe PTPN1 ( $\mathrm{p}>0,05)$. Peluang gangguan metabolisme pada kelompok BBLN dengan polimorfisme Cys981Tyr gen PTPN1 meningkatkan tekanan darah diastol sebesar 1,11 kali dibandingkan dengan kelompok BBLN dengan gen PTPN1 alamiah, sedangkan pada kelompok BBLR peluang terjadi variabel sindrom metabolik lainnya tidak ada perbedaan antara genotipe PTPN1

Polimorfisme Gly972Arg gen IRS-1 merupakan prediktor yang paling dominan berhubungan dengan lingkar perut, tekanan darah diastol dan gangguan kadar trigliserida; sedangkan polimorfisme Cys981Tyr gen PTPN1 merupakan prediktor yang paling dominan berhubungan dengan tekanan darah sistol, dan gangguan kadar HDL, serta BBLR merupakan prediktor yang paling dominan berhubungan dengan gangguan gula darah puasa.

Simpulan, polimorfisme Gly972Arg gen IRS1 dapat dijadikan prediktor kelainan variabel sindrom metabolik seperti lingkar perut, IMT, tekanan darah diastol, dan gangguan kadar trigliserida. Polimorfisme Cys981Tyr gen PTPN1 merupakan prediktor peningkatan tekanan darah sistol, sedangkan BBLR merupakan prediktor peningkatan kadar gula darah puasa.

\section{Daftar Pustaka}

1. Cowie CC, Rust KF, Byrd-Holt DD, Gregg EW, Ford ES, Geiss LS, dkk. Prevalence of diabetes and high risk for diabetes using A1C criteria in the U.S. population in 1988-2006. Diabetes Care. 2010;33(3):562-8.

2. Grundy SM, Cleeman JI, Daniels SR, Donato KA, Eckel RH, Franklin BA, dkk. Diagnosis and management of the metabolic syndrome: an American Heart Association/National Heart, Lung, and Blood Institute Scientific Statement. Circulation. 2005;112(17):273552.

3. Misra A, Khurana L. Obesity and the metabolic syndrome in developing countries. J Clin Endocrinol Metab. 2008;93(11 Suppl 1):S9-30.

4. DeFronzo RA. Pathogenesis of type 2 diabetes mellitus. Med Clin North Am. 2004;88(4):787-835.

5. Barker DJ. The developmental origins of adult disease. J Am Coll Nutr. 2004;23(6 Suppl):588-95S.

6. Sukesi L, Sjukrudin ES, Purnomowati A, Widjaja G, Fadlyana E, Alisjahbana B. The association between prenatal and or post natal growth disorder and lipid profile in adolescents aged 12-15 years old in Tanjungsari Subdistrict, Sumedang, West Java. Acta Med Indones. 2005;37(3):149-56.

7. McGettrick AJ, Feener EP, Kahn CR. Human insulin receptor substrate-1 (IRS1) polymorphism G972R causes IRS-1 to associate with the insulin receptor and inhibit receptor autophosphorylation. J Biol Chem. 2005;280(8):6441-6.

8. Asante-Appiah E, Kennedy BP. Protein tyrosine phosphatases: the quest for negative regulators of insulin action. Am J Physiol Endocrinol Metab. 2003;284(4):E663-70.

9. Jellema A, Zeegers MP, Feskens EJ, Dagnelie PC, Mensink RP. Gly972Arg variant in the insulin receptor substrate-1 gene and association with Type 2 diabetes: a meta-analysis of 27 studies. Diabetologia. 2003;46(7):990-5. 
10. Kashyap SR, Defronzo RA. The insulin resistance syndrome: physiological considerations. Diab Vasc Dis Res. 2007;4(1):13-9.

11. Bento JL, Palmer ND, Mychaleckyj JC, Lange LA, Langefeld CD, Rich SS, dkk. Association of protein tyrosine phosphatase 1B gene polymorphisms with type 2 diabetes. Diabetes. 2004;53(11):3007-12.

12. Mok A, Cao H, Zinman B, Hanley AJG, Harris SB, Kennedy BP, dkk. A single nucleotide polymorphism in protein tyrosine phosphatase PTP-1B is associated with protection from diabetes or impaired glucose tolerance in Oji-Cree. J Clin Endocrinol Metab. 2002;87(2):724-7.

13. Echwald SM, Bach $H$, Vestergaard $H$, Richelsen B, Kristensen K, Drivsholm T, dkk. A P387L variant in protein tyrosine phosphatase-1B (PTP-1B) is associated with type 2 diabetes and impaired serine phosphosrylation of PTP-1B in vitro. Diabetes. 2002;51(1):1-6.

14. Palmer ND, Bento JL, Mychaleckyj JC, Langefeld CD, Campbell JK, Norris JM, dkk. Association of protein tyrosine phosphatase 1B gene polymorphisms with measures of glucose homeostasis in Hispanic Americans. Diabetes. 2004;53(11):3013-9.

15. Bezerra RM, de Castro V, Sales T, Passini R
Jr, Marba ST, Saad ST, dkk. The Gly972Arg polymorphism in insulin receptor substrate-1 is associated with decreased birth weight in a population-based sample of Brazilian newborn. Diab Care. 2002;25(3):550-3.

16. Villuendas G, Botella-Carretero JI, Roldan B, Sancho J, Escobar-Morreale HF, San Millan JL. Polymorphisms in the insulin receptor substrate-1 (IRS-1) gene and the insulin receptor substrate-2 (IRS-2) gene influence glucose homeostatis and body mass index in women with polycystic ovary syndrome and non-hyperandrogenic controls. Human Reprod. 2005;20(11):3184-91.

17. Zeggini E, Parkinson J, Halford S, Owen KR, Frayling TM, Walker M, dkk. Association studies of insulin receptor substrate 1 gene (IRS1) variants in type 2 diabetes samples enriched for family history and early age of onset. Diabetes. 2004;53(12):3319-22.

18. Le Fur S, Le Stunff $C$, Bougnères $P$. Increased insulin resistance in obese children who have both 972 IRS-1 and 1057 IRS-2 polymorphisms. Diabetes. 2002;51(Supp1 3):S304-7.

19. Avramoglu RK, Qiu W, Adeli K. Mechanisms of metabolic dyslipidemia in insulin resistant states: deregulation of hepatic and intestinal lipoprotein secretion. Front Biosci. 2003;8:d464-76. 